\title{
PENGARUH BENTUK SOAL DAN MOTIVASI SISWA TERHADAP KETERAMPILAN MEMBACA BAHASA JERMAN
}

\author{
Dwi Yoga Peny Hadyanti \\ Universitas Negeri Jakarta
}

\begin{abstract}
The purpose of this research is to identify the influence of test types and student's motivation toward the German language achievement in Reading Comprehension Skill based on the learning achievement of the experiment and control group. The population of this research are Grade XII student of SMA Negeri 3I Jakarta. Research samples are students of grade XII IPA I and XII IPA 3 of SMA Negeri 3 I Jakarta. Data are obtained by using random sampling. The research is conducted by using the "quasi experiment" method with a "treatment by level" design. Two ways ANOVA technique and "Tukey" test are used to analyze the collected data. Before the data are analyzed, homogeneity and normality test are applied to see whether or not the data meet the requirement. The result of this research indicates that: (I) the different form of test (Short Answer and Multiple Choice) significantly influence the achievement of German language learning in terms of Reading Comprehension, (2) an interaction exists between the form of the test and student's motivation and their achievement of learning German language, (3) a significant difference was present when Short Answer is applied to the group of students with high motivation, and Multiple Choice is given to other group of students, and (4) there is no difference between the group of students with low motivation to whom the Short Answer test is used and the group of students to whom Multiple Choice test is used.
\end{abstract}

\section{Keywords}

Form of test, student motivation of German study, the achievement of German language for reading comprehension

\begin{abstract}
ABSTRAK
Penelitian ini bertujuan untuk mengetahui pengaruh bentuk soal dan motivasi siswa terhadap keterampilan membaca bahasa Jerman melalui prestasi belajar antara kelompok eksperimen dan kontrol. Populasi penelitian ini adalah siswa kelas XII IPA SMA Negeri 3I Jakarta. Sampel penelitian ini adalah siswa kelas X IPA I dan XII IPA 3 SMA Negeri 3 I Jakarta. Pengambilan sampel dilakukan dengan teknik random sampling. Penelitian ini menggunakan metode Quasi Experiment dengan desain treatment by level. Data yang terkumpul dianalisis dengan menggunakan teknik analisis varian (ANAVA) dua jalur. Hasil penelitian menunjukkan bahwa: (I) terdapat perbedaan yang signifikan antara pemberian tes bentuk Short Answer dengan tes bentuk Multiple Choice terhadap prestasi belajar bahasa Jerman dalam Keterampilan Membaca, (2) terdapat interaksi antara bentuk soal dengan motivasi siswa terhadap prestasi belajar siswa dalam Keterampilan Membaca Bahasa Jerman, (3) terdapat perbedaan yang sangat signifikan antara kelompok siswa yang memiliki motivasi tinggi yang diberikan tes bentuk Short Answer dengan tes bentuk Multiple Choice, dan (4) tidak terdapat perbedaan antara kelompok siswa yang memiliki motivasi rendah yang diberikan tes bentuk Short Answer dengan kelompok siswa yang diberi tes bentuk Multiple Choice.
\end{abstract}

\section{Kata Kunci}

Bentuk soal, motivasi siswa pada mata pelajaran bahasa Jerman, prestasi belajar bahasa Jerman dalam keterampilan membaca

\section{Pendahuluan}

Peningkatan pendidikan terus dilakukan dengan berbagai cara. Tidak hanya peningkatan sarana prasarana melainkan juga peningkatan sumber daya manusia (dalam hal ini peningkatan kompetensi pendidik dan tenaga kependidikan). Dengan makin besarnya otoritas guru dalam mendesain sebuah pembelajaran, maka guru menjadi ujung tombak keberhasilan pendidikan. Karena itu pula kompetensi guru menjadi hal yang 
sangat penting. Dengan kompetensinya guru akan dapat melaksanakan kurikulum yang telah disusunnya sendiri dengan maksimal, mulai dari merencanakan pembelajaran, melaksanakan pembelajaran, dan mengevaluasinya. Karena profesionalismenya seorang guru dituntut melalui kompetensinya dalam hal penguasaan kurikulum dan didalamnya penguasaan metode pengajaran dan penguasaan penilaian, serta penguasaan materi (Surapranata, 2007)

Sebagai tuntutan dari perubahan kurikulum terjadi juga perubahan konsep dalam pembelajaran bahasa. Pembelajaran bahasa harus dapat menghasilkan kompetensi yang diharapkan, termasuk pembelajaran bahasa Jerman. Standar Kompetensi dalam bahasa Jerman yaitu: (I) MENDENGARKAN: Memahami wacana lisan berbentuk paparan atau dialog sederhana tentang suatu tema; (2) BERBICARA: Mengungkapkan informasi secara lisan dalam bentuk paparan atau dialog sederhana tentang suatu tema; (3) MEMBACA: Memahami wacana tulis berbentuk paparan atau dialog sederhana tentang suatu tema; dan (4) MENULIS: Mengungkapkan informasi secara tertulis dalam bentuk paparan atau dialog sederhana tentang suatu tema (KTSP, 2006).

Berdasarkan standar kompetensi yang diharapkan itu maka jelaslah bahwa akhir dari pembelajaran bahasa adalah kemampuan siswa menggunakan bahasa yang dipelajarinya dalam empat keterampilan, yaitu: menyimak, berbicara, membaca, dan menulis. Hal ini dapat diketahui apabila guru melakukan tes. Menurut Sumarna, dengan tes guru memperoleh informasi tentang keberhasilan siswa dalam mencapai tujuan yang ditentukan, meliputi (standar kompetensi, kompetensi dasar, dan indikator). Selain itu juga guru dapat dengan mudah mengetahui siswa yang sudah menguasai atau belum menguasai dan dapat mendeteksi pembelajaran yang sudah dilakukan. Melalui tes guru juga dapat memantau tentang perkembangan tertentu (Surapranata, 2007). Penilaian juga merupakan salah satu kegiatan untuk mengukur dan menilai tingkat pencapaian kurikulum. Penilaian juga untuk mengetahui kekuatan dan kelemahan proses pembelajaran, sehingga dapat menjadi dasar menentukan apakah materi tertentu akan dapat dilanjutkan ataukah diulang kembali (Surapranata, 2007).
Seperti diketahui bahwa proses belajar mengajar tidak hanya meliputi persiapan pembelajaran dan proses pembelajaran, melainkan juga sampai dengan pelaksanaan evaluasi pembelajaran. Guru tidak bisa menutup mata bahwa kualitas pembelajaran Bahasa belumlah memuaskan. Masih banyak kekurangan di sana sini, misalnya dapat dilihat dari hasil Ujian Nasional (UN) untuk mata pelajaran Bahasa. Hal ini berlaku juga untuk pembelajaran bahasa Jerman. Dengan demikian hasil pembelajaran bahasa masih harus ditingkatkan lagi.

Mengapa hal ini bisa terjadi. Banyak faktor yang dapat mempengaruhi hal ini. Antara lain keterbatasan guru dalam menyusun tes. Keterbatasan ini meliputi ketidaktahuan guru tentang prinsip tes, bentuk tes, dan tujuan tes itu sendiri. Banyak guru juga kurang memahami kapan dan untuk apa mereka memberikan tes. Apakah hanya untuk mengisi waktu karena guru tidak mempersiapkan sebuah skenario pembelajaran? Tentu hal ini sedikit banyak masih terjadi. Hal lain yang merupakan penyebab kurangnya guru mendalami penilaian secara rinci karena secara khusus guru tidak mempunyai latar belakang pendidikan formal.

Bahkan banyak yang memberikan tes sebagaimana mereka menerima tes sebelumnya seperti pada waktu mereka menjadi siswa. Hal ini tentulah sangat merugikan. Kalau saja tes yang didapatnya merupakan tes yang baku (terstandar), tentulah akan lebih baik. Jadi pengetahuan guru minimal tentang prinsip tes sangatlah penting. Tes hendaklah mengukur apa yang telah dipelajari. Karena tes merupakan alat yang dapat memberikan informasi guna merumuskan berbagai keputusan penting dalam pengajaran. Dalam pengembangannya tespun harus sesuai dengan tuntutan serta ciri-ciri tes yang bermutu Djiwandono, 2008).

Selain hal tersebut di atas, pemahaman tentang bentuk soal mutlak diperlukan. Apakah bentuk soal yang akan digunakan sudah cocok untuk mengukur prestasi belajar yang diinginkan. Apakah bentuk soal yang dipilih guru dapat diandalkan sebagai alat ukur yang tepat. Karena masingmasing bentuk soal mempunyai karakteristik yang berbeda dan kekurangan serta kelebihannya. Ada dua bentuk tes yang dapat digunakan guru, yaitu: tes lisan dan tertulis. Tes tertulis meliputi 
beberapa variasi lagi, seperti tes essay dan tes obyektif. Salah satu tes essay adalah tes bentuk Short Answer. Sedangkan tes obyektif antara lain: melengkapi, menjodohkan, Multiple Choice, dan menentukan benar atau salah.

Pada umumnya siswa lebih senang mengerjakan soal-soal tes obyektif terutama Multiple Choice daripada bentuk tes Short Answer. Mereka merasa mudah untuk mengisinya karena pilihan sudah tersedia. Hal inilah yang menyebabkan siswa beranggapan bahwa soal bentuk Multiple Choice lebih mudah daripada soal bentuk Short Answer, walaupun pada kenyataannya belum tentu seperti itu. Hal inilah yang juga mempengaruhi prestasi belajar siswa.

Berdasarkan pengalaman pribadi selama menjadi guru di beberapa sekolah, setelah siswa terbiasa mengerjakan soal-soal Short Answer siswa menjadi lebih mudah mengerjakan soal soal bentuk Multiple Choice, terutama pada saat mengerjakan tes keterampilan membaca. Hal ini juga ditegaskan oleh Wiersma dan Jurs, bahwa soal-soal Short Answer dan Multiple Choice tepat digunakan untuk mengukur kemampuan membaca bermutu (Wiersma dan Jurs, 1990). Hughes (2005) menambahkan bahwa Short Answer juga merupakan alternatif terutama untuk tes membaca, di mana siswa harus mempersiapkan jawaban singkat.

Selain hal tersebut di atas motivasi juga mempunyai peranan dalam tercapainya prestasi belajar. Seperti diketahui motivasi siswa juga relatif tidak stabil. Kadang-kadang siswa sangat termotivasi untuk belajar tapi terkadang motivasi siswa untuk belajar hilang. Hal ini terjadi tentu karena ada sebabnya. Hal yang sangat berpengaruh terhadap motivasi siswa antara lain adalah kompetensi guru dalam mengelola pembelajaran. Berbicara pengelolaan pembelajaran sangatlah luas, karena meliputi beberapa aspek yang saling berkaitan antara lain: cara guru menyampaikan informasi atau materi, materi tersebut disampaikan dengan menarik atau tidak, atau materi yang disampaikan juga bermanfaat di kemudian hari. Faktor kegunaan sangatlah menjadi hal yang diperhitungkan siswa untuk mempelajari hal tersebut lebih jauh.

Banyak lagi faktor yang menunjukkan kurangnya keberhasilan dalam pembelajaran bahasa seperti kurangnya kompetensi guru mulai dari merencanakan pembelajaran sampai dengan mengevaluasi hasil pembelajaran itu sendiri. Juga pengaruh dari pihak siswa seperti motivasi siswa yang rendah terhadap pembelajaran bahasa. Berdasarkan latar belakang, maka penulis akan meneliti tentang pengaruh bentuk soal Short Answer dan bentuk soal Multiple Choice dan motivasi siswa terhadap prestasi belajar siswa dalam keterampilan membaca mata pelajaran bahasa Jerman. Mengapa bentuk soal Short Answer dan bentuk soal Multiple Choice? Karena kedua bentuk soal tersebut tepat digunakan untuk mengetahui prestasi belajar siswa dalam keterampilan membaca.

\section{Metode Penelitian}

Penelitian ini menggunakan metode eksperimen (Quasi Experiment). Eksperimen merupakan kajian penelitian dalam situasi nyata (realitas), dengan cara memanipulasikan satu variabel bebas atau lebih dalam kondisi yang dikontrol cermat oleh pembuat eksperimen sejauh yang dimungkinkan oleh situasinya (Kerlinger, 2000). Sedangkan desain penelitian ini menggunakan treatment by level design dengan desain faktorial $2 \times 2$.

Data penelitian berupa hasil instrumen motivasi siswa dan hasil instrumen prestasi belajar siswa. Teknik pengumpulan data adalah dengan kuesioner dan tes. Adapun prosedur analisis data melalui tes prestasi belajar bahasa Jerman dan hasil dari kuesioner untuk mengetahui motivasi siswa. Data prestasi belajar bahasa Jerman diperoleh dengan mengunakan instrumen yang dikembangkan sendiri oleh peneliti. Data motivasi siswa diperoleh dengan menggunakan tes skala motivasi, yaitu: skala Likert (I, 2, 3, 4, dan 5). Data hasil kedua tes tersebut kemudian diolah dengan analisis deskriptif dan inferensial untuk menguji hipotesis penelitian.

Pengujian hipotesis penelitian ini dilakukan dengan menggunakan teknik analisis variansi (ANAVA) dua jalan sesuai rancangan faktorial 2 x 2 pada taraf signifikansi $\alpha=0,05$. sebelum menggunakan ANAVA terlebih dahulu dilakukan uji persyaratan analisis yang meliputi uji normalitas dan uji homogenitas variansi. Uji normalitas bertujuan untuk melihat kenormalan sampel dengan menggunakan uji Liliefors 
(Sudjana, 1996). Untuk mengetahui homogenitas varians dilakukan dengan menggunakan uji Bartlett (Sudjana, 1996).

\section{Hasil Penelitian dan Pembahasan}

Pada dasarnya tujuan penelitian ini adalah untuk mendapatkan upaya pembaharuan dalam proses pembelajaran melalui pemberian bentuk tes dilihat dari motivasi siswa yang pada akhirnya dapat meningkatkan prestasi belajar bahasa Jerman siswa. Berdasarkan hasil temuan tersebut maka akan dilakukan pembahasan terhadap hasil temuan tersebut.

Berdasarkan hasil penelitian pada dua kelompok siswa dengan perlakuan bentuk tes yang berbeda menunjukkan adanya perbedaan prestasi belajar bahasa Jerman antara kelompok siswa yang mengerjakan tes bentuk Short Answer dan kelompok siswa yang mengerjakan tes bentuk Multiple Choice

Hal ini disebabkan karena untuk menjawab soal Short Answer siswa harus mempersiapkan jawaban singkat, dan menjawab dengan singkat, berupa kata, prase, kalimat, atau nama tempat, nama tokoh dan lambang (Surapranata, 2007).

Siswa juga akan mempunyai kemampuan untuk mengidentifikasikan kata, memperkirakan arti kata yang tidak diketahui berdasarkan konteks, menentukan pernyataan tersebut merupakan opini atau fakta, dan dapat juga digunakan untuk menentukan paragraf yang tepat. Dibandingkan dengan soal Multiple Choice di mana siswa memilih jawaban benar berdasarkan pilihan jawaban yang tersedia, sedang pada penyelesaian soal Short Answer kemungkinan siswa menebak jawaban sangatlah kecil (Surapranata, 2007). Jadi siswa tidak hanya dituntut mengenali jawaban saja seperti halnya pada bentuk tes Multiple Choice. Tes bentuk Short Answer pun dapat mengungkap aspek kognitif tingkat tinggi dan dapat meningkatkan kemampuan dan keterampilan membaca (Wiersmadan Jurs, 1990).

Melalui penulisan ini dapat dibuktikan bahwa secara keseluruhan prestasi belajar bahasa Jerman yang diberi tes Short Answer lebih tinggi dibandingkan dengan yang diberi tes bentuk Multiple Choice. Hal ini menunjukkan bahwa salah satu upaya untuk meningkatkan prestasi belajar bahasa Jerman dalam keterampilan membaca dapat dilakukan dengan pemberian tes formatif bentuk Short Answer.

Perbedaan prestasi belajar bahasa Jerman merupakan pengaruh dari bentuk tes dan motivasi siswa. Dalam penelitian ini secara sangat signifikan dapat diperlihatkan interaksi di antara kedua variabel tersebut.

Bagi siswa dengan motivasi tinggi akan lebih mampu mengapresiasikan dan berinteraksi dengan soal yang ada dalam tes formatif, baik yang sudah dapat diselesaikan maupun soal yang belum dapat dijawab atau memerlukan bantuan guru. Siswa tersebut tidak terpengaruh akan bentuk tes formatif. Sedangkan bagi siswa yang dengan motivasi rendah akan berusaha seoptimal mungkin supaya dapat menyelesaikan soal-soal tes bentuk Short Answer. Karena motivasi selalu berkait dengan kebutuhan, siswapun mempunyai kebutuhan untuk mengatasi kesulitan. Anak didik dapat tergerak hatinya karena motivasi untuk belajar bersama teman-temannya (Djamarah dan Zain, 2006). Jadi apabila mereka diberikan tes formatif bentuk Short Answer tepat sekali, artinya tujuan pembelajaran yang telah ditetapkan akan tercapai secara optimal. Karena tes yang mendapat perhatian khusus dari guru juga dapat menjadi motivasi intrinsik bagi siswa (Douglas, 200I). Siswa mempunyai motivasi kuat, mempunyai banyak energi pula untuk belajar. Hasil belajarnyapun akan menjadi optimal kalau ada motivasi yang tepat (Sardiman, 1986).

Berdasarkan uraian yang telah dipaparkan di atas terbukti bahwa terdapat interaksi antara pemberian tes formatif dengan motivasi siswa pada pembelajaran bahasa Jerman yang memberikan perbedaan pengaruh terhadap prestasi belajar bahasa Jerman dalam keterampilan membaca. Adanya interaksi membuktikan bahwa masing-masing pengaruh bentuk tes, baik bentuk Short Answer maupun Multiple Choice memberikan pengaruh yang berbeda terhadap prestasi belajar bahasa Jerman jika disampaikan pada kelompok siswa yang memiliki motivasi yang berbeda.

Pengujian pada hipotesis ketiga menunjukkan bahwa sekor rata-rata prestasi belajar bahasa Jerman secara keseluruhan kelompok siswa yang memiliki motivasi tinggi yang mengerjakan tes Short Answer berbeda dengan kelompok siswa yang mengerjakan tes Multiple 
Choice. Terbukti bahwa terdapat perbedaan yang sangat signifikan antara dua kelompok tersebut. Secara keseluruhan prestasi belajar bahasa Jerman kelompok siswa yang memiliki motivasi tinggi yang diberi tes bentuk Short Answer pun lebih tinggi daripada kelompok siswa yang diberi tes bentuk Multiple Choice. Perbedaan tersebut disebabkan karena motivasi adalah salah satu faktor yang dapat meningkatkan kualitas pembelajaran, karena siswa akan belajar dengan sungguh sungguh apabila memiliki motivasi yang tinggi (Mulyasa, 2007). Makin tinggi motivasi seseorang maka akan makin besarlah keberhasilan belajarnya (Oppolzer, 2008). Jadi siswa yang memiliki motivasi kuat, akan mempunyai banyak energi untuk melakukan kegiatan belajar, sehingga prestasi belajar akan menjadi optimal kalau ada motivasi yang tepat. Namun motivasi harus dijaga, antara lain melalui penjelasan secara konkret kepada siswa apa yang dapat dilakukan pada akhir pengajaran, serta bantuan dalam kesulitan belajar siswa secara individual maupun kelompok. Hal ini dilakukan guru melalui umpan balik dengan menjelaskan secara konkret kepada siswa apa yang dapat dilakukan pada akhir pengajaran (Oppolzer, 2008: 146), pada kelas yang diberi tes bentuk Short Answer. Sehingga prestasi kelompok siswa dengan motivasi tinggi pada kelas yang diberi tes Short Answer lebih tinggi.

Berdasarkan hasil analisis menggambarkan bahwa sekor rata-rata prestasi belajar bahasa Jerman siswa yang memiliki motivasi rendah yang diberi tes bentuk Short Answer lebih rendah dari pada sekor rata-rata siswa yang memiliki motivasi rendah yang diberi tes bentuk Multiple Choice. Sehingga dapat disimpulkan bahwa pemberian perlakuan untuk kedua bentuk tes tidak mempunyai pengaruh yang signifikan pada kelompok siswa yang memiliki motivasi rendah.

Dari uraian hasil penelitian tersebut di atas disimpulkan bahwa pemberian perlakuan kedua bentuk tes dan motivasi siswa mempunyai pengaruh yang tidak signifikan terhadap prestasi belajar Bahasa Jerman. Khususnya, pemberian perlakuan tes bentuk Short Answer akan mempunyai pengaruh yang sangat signifikan jika diberikan kepada kelompok siswa yang memiliki motivasi tinggi. Namun, pemberian perlakuan tes Short Answer ternyata tidak berpengaruh jika diberikan kepada kelompok siswa yang mempunyai motivasi rendah.

Penyebabnya adalah motivasi belajar siswa yang lemah, sehingga menimbulkan melemahnya kegiatan belajarnya. Apalagi untuk kelas yang diberi tes bentuk Short Answer, di mana siswa harus mempersiapkan jawaban singkat dan memberikan jawaban singkat (Hughes, 2005) dan tidak dapat melakukan tebakan dalam memberikan jawaban seperti halnya pada kelompok siswa yang diberi tes bentuk Multiple Choice merupakan hal yang sulit untuk siswa dengan motivasi rendah.

\section{Kesimpulan}

Berdasarkan hasil pengujian hipotesis dan pembahasan hasil penelitian dapat disimpulkan bahwa:

I. Secara keseluruhan bahwa prestasi belajar siswa dalam keterampilan membaca bahasa Jerman yang mengerjakan tes bentuk Short Answer lebih tinggi dibandingkan kelompok siswa yang mengerjakan tes bentuk Multiple Choice.

2. Terdapat interaksi bentuk tes Short Answer dan Multiple Choice dengan motivasi siswa pada prestasi belajar siswa dalam keterampilan membaca bahasa Jerman.

3. Prestasi belajar siswa dalam keterampilan membaca bahasa Jerman untuk kelompok siswa yang memiliki motivasi tinggi yang mengerjakan tes bentuk Short Answer lebih tinggi dari kelompok siswa yang memiliki motivasi tinggi yang mengerjakan tes bentuk Multiple Choice.

4. Prestasi belajar siswa dalam keterampilan membaca bahasa Jerman untuk siswa yang memiliki motivasi rendah yang mengerjakan tes bentuk Short Answer lebih rendah dari kelompok siswa yang memiliki motivasi rendah yang mengerjakan tes bentuk Multiple Choice.

Berdasarkan hal tersebut secara umum dapat disimpulkan bahwa terbukti adanya pengaruh bentuk tes Short Answer dan Multiple Choice dan motivasi siswa terhadap prestasi belajar siswa dalam keterampilan membaca bahasa Jerman. 


\section{Daftar Pustaka}

Brown, H. Douglas. (200I). Teaching by PrinciplesAn Interactive Approach to Language Pedagogy. San Fransisco: Addison Wesley Longman, Inc.

Djamarah, Syaiful Bahri dan Aswan Zain. (2006). Belajar Mengajar. Jakarta: PT Rineka Cipta.

Djiwandono, Sri Esti Wuryani. (2008). Psikologi Pendidikan. Jakarta: PT Grasindo.

Hughes, Arthur. (2005). Testing for Language Teacher. Cambridge University Press.

Kerlinger, Fred N. (20/3). Asas-Asas Penelitian Behavioral, Gadjah Mada University Press.

Mulyasa. (2007). Menjadi Guru PofesionalMenciptakan Pembelajaran Kreatif dan
Menyenangkan. Bandung: PT Remaja Rosdakarsa.

Oppolzer, Ursula. (2008). Super Lernen Cetakan ke 6, Hannover: Humboldt.

Sardiman. (1986). Integrasi \& Motivasi-Belajar Mengajar. Jakarta: PT Rajagrafindo Persada.

Sudjana. (1996). Metode Statistik. Bandung: Tarsito.

Surapranata, Sumarna. (2007). Panduan Penulisan Tes Tertulis-Implementasi Kurikulum 2004 Bandung: PT Remaja Rosdakarsa.

Wiersma, William and Stephhen G. Jurs. (1990). Educational Measurement \& Testing. Massachussetts: Allyn \& Bacon. 